\title{
Pengaruh Current Ratio (CR), Net Profit Margin (NPM), dan Kebijakan Dividen terhadap Harga Saham pada Perusahaan Consumer Goods Yang Terdaftar Di Bursa Efek Indonesia (BEI) Pada Periode 2013-2017
}

\author{
Hottua Samosir \\ Universitas Prima Indonesia \\ hottuarealy@gmail.com
}

Krisna Emalini M. Ginting

Universitas Prima Indonesia

krisnaemaliniginting@gmail.com

\author{
Enda Noviyanti Simorangkir \\ Universitas Prima Indonesia \\ endanoviyantisimorangkir@unprimdn.ac.id
}

Yeyen Syarival Banjarnahor
Universitas Prima Indonesia
yeyensyarival1994@gmail.com
Andhy Stephanus

Universitas Prima Indonesia andhy.stephanus@yahoo.com

Meita Pitriyani Br Sitepu Universitas Prima Indonesia meithafitriyani@gmail.com

\begin{abstract}
This research is meant to find out the effects of current ratio (cr), net profit margin (npm) and dividend policy on stock price in consumer goods companies which are listed in Indonesia Stock Exchange (IDX)in 2013-2017 periods. Sample determination using purposive sampling method and sample studied are 19 companies. Method of data analysis using multiple linear regression. The results of this research shows that simultaneously and partial CR, NPM and Dividend Policy have positive and significant effects to the stock price in consumer goods companies which are listed in Indonesia Stock Exchange in 2013-2017 periods. Keywords : Current Ratio, Net Profit Margin, Dividend Policy, Stock Price
\end{abstract}

\begin{abstract}
Abstrak
Penelitian ini bertujuan untuk menguji pengaruh current ratio (CR), net profit margin (NPM) dan kebijakan dividen terhadap harga saham pada perusahaan consumer goods yang terdaftar di Bursa Efek Indonesia (BEI) periode 2013-2017. Penentuan sampel menggunakan metode purposive sampling dan sampel yang diteliti adalah 19 perusahaan. Metode analisis data menggunakan analisis regresi linear berganda. Hasil penelitian ini menunjukkan bahwa secara simultan dan parsial CR, NPM dan Kebijakan Dividen berpengaruh positif dan signifikan terhadap harga saham pada perusahaan consumer goods yang terdaftar di Bursa Efek Indonesia periode 2013-2017.
\end{abstract}

Kata Kunci : Current Ratio, Net Profit Margin, Kebijakan Dividen, Harga Saham

I. Pendahuluan

Current ratio menunjukkan sejauh mana aktiva lancar mampu menutupi kewajiban jangka pendek perusahaan. Semakin besar perbandingan aktiva lancar dan kewajiban lancar, maka semakin tinggi kemampuan perusahaan untuk menutupi kewajiban jangka pendeknya. Current ratio yang rendah biasanya dianggap menunjukkan terjadinya masalah dalam likuidasi di perusahaan. Sebaliknya, current ratio yang tinggi juga kurang bagus. Karena menunjukkan banyaknya dana menganggur yang pada akhirnya dapat mengurangi kemampu labaan perusahaan.

Adapun salah satu ukuran perusahaan dalam mendapatkan laba yang maksimal dapat dilihat dari rasio-rasio yang menunjukkan perkembangan atau kemunduran dari operasional normal perusahaan tersebut. Hal ini dapat dilihat dari salah satu rasio, yaitu Net Profit Margin (NPM). Rasio ini mengukur kemampuan perusahaan dalam menghasilkan keuntungan pada tingkat penjualan, aset dan modal usaha. Apabila 
nilai NPM tinggi, ini menunjukkan bahwa kemampuan perusahaan dalam menghasilkan laba cukup maksimal, dengan demikian hal ini memberikan peluang bagi para investor untuk menanamkan saham di perusahaan.

Sebaliknya, apabila nilai NPM rendah, ini menunjukkan penjualan yang terlalu rendah untuk tingkat biaya tertentu. Secara umum, hal ini menunjukkan ketidakefisienan manajemen.

Begitu pula kebijakan deviden sangat penting karena mempengaruhi kesempatan investasi perusahaan, harga saham, struktur finansial, arus pendanaan dan posisi likuiditas. Dengan perkataan lain, kebijakan deviden menyediakan informasi mengenai performa perusahaan. Oleh karena itu, masing-masing perusahaan menetapkan kebijakan dividen yang berbeda-beda. Laba yang diperoleh perusahaan, selain diberikan kepada pemegang saham sebagai dividen, dapat juga ditahan untuk diinvestasikan kembali. Kebijakan dividen yang menghasilkan tingkat dividen yang semakin meningkat dari tahun ke tahun akan meningkatkan kepercayaan para investor, dan secara tidak langsung memberikan informasi kepada para investor bahwa kemampuan

Perkembangan Aktiva Lancar, Laba Bersih, Deviden, dan Harga Saham Perusahaan periode 2013-

2017

(Dalam Jutaan Rupiah)

\begin{tabular}{|c|c|c|c|c|c|c|}
\hline No & Kode & Thn & Aktiva Lancar & Laba Bersih & Dividen & Harga Saham \\
\hline \multirow[t]{5}{*}{1} & \multirow[t]{5}{*}{ ICBP } & 2013 & 11.321 .715 & 2.235 .040 & 1.116 .480 & 10.200 \\
\hline & & 2014 & 13.603 .527 & 2.531 .681 & 1.128 .410 & 13.100 \\
\hline & & 2015 & 13.961 .500 & 2.923 .148 & 1.320 .458 & 13.475 \\
\hline & & 2016 & 15.571 .362 & 3.631 .301 & 1.544 .392 & 8.575 \\
\hline & & 2017 & 16.579 .331 & 3.543 .173 & 1.942 .822 & 8.900 \\
\hline \multirow[t]{5}{*}{$2 \mathrm{i}$} & \multirow[t]{5}{*}{ DVLA } & 2013 & 913.983 & 125.796 & 52.640 & 2.200 \\
\hline & & 2014 & 925.293 & 80.929 & 24.640 & 1.690 \\
\hline & & 2015 & 1.043 .830 & 107.894 & 78.114 & 1.300 \\
\hline & & 2016 & 1.068 .967 & 152.083 & 39.057 & 1.755 \\
\hline & & 2017 & 1.175 .655 & 162.249 & 111.592 & 1.960 \\
\hline \multirow[t]{5}{*}{3} & \multirow[t]{5}{*}{ INDF } & 2013 & 32.464 .497 & 3.416 .635 & 2.176 .776 & 6.600 \\
\hline & & 2014 & 40.995 .736 & 5.146 .323 & 1.734 .632 & 6.750 \\
\hline & & 2015 & 42.816 .745 & 3.709 .501 & 2.508 .522 & 5.175 \\
\hline & & 2016 & 28.985 .443 & 5.266 .906 & 1.964 .713 & 7.925 \\
\hline & & 2017 & 32.515 .399 & 5.145 .063 & 2.734 .794 & 7.625 \\
\hline
\end{tabular}

Sumber : www.idx.co.id

Berdasarkan tabel I.1 terlihat bahwa ICBP pada tahun 2015 memiliki aktiva lancar sebesar Rp

perusahaan dalam menciptakan laba perusahaan semakin meningkat.

Sementara itu, harga saham biasa diterbitkan oleh perusahaan dengan harga pasar untuk menarik investor bergabung di perusahaan. Saham dikenal memiliki karakteristik high riskhigh return. Artinya, saham itu surat berharga yang memberikan peluang keuntungan yang tinggi namun juga berpotensi risiko tinggi bagi perusahaan dan para investor. Saham memungkinkan modal mendapatkan keuntungan (capital gain)dalam jumlah besar dalam waktu singkat. Namun seiring dengan berfluktuasinya harga saham, saham juga dapat membuat investor mengalami kerugian besar dalam waktu singkat.

Berikut ini adalah tabel current ratio, net profit margin, kebijakan deviden dan harga saham tahun 2013 -2017 pada perusahaan consumer goods yang terdaftar di Bursa Efek Indonesia yang dapat menggambarkan perkembangan setiap variabel yang terjadi. Hal ini ditunjukkan dengan mengangkat tiga perusahaan sebagai perwakilan dari seluruh perusahaan consumer goods yang terdaftar di Bursa Efek Indonesia.

Tabel 1.1 
Sedangkan harga saham pada tahun 2015 sebesar Rp 13.475 dan pada tahun 2016 mengalami penurunan sebesar Rp 4.900 (-36,3\%). Hal ini tidak sejalan dengan teori, dimana seharusnya apabila aktiva lancar meningkat maka harga saham juga meningkat.

DVLA pada tahun 2014 memiliki laba bersih sebesar Rp 80.929 dan pada tahun 2015 mengalami kenaikan sebesar Rp 26.964 (33,3\%). Sedangkan harga saham pada tahun 2014 sebesar Rp 1.690 dan pada tahun 2015 mengalami penurunan sebesar Rp 390 (-23\%). Hal ini tidak sejalan dengan teori, dimana seharusnya apabila laba bersih meningkat maka harga saham juga meningkat.

INDF pada tahun 2014 memiliki dividen sebesar Rp 1.734.632 dan pada tahun 2015 mengalami kenaikan sebesar Rp 773.890 (44,6\%). Sedangkan harga saham pada tahun 2014 sebesar Rp 6.750 dan pada tahun 2015 mengalami penurunan sebesar Rp 1.575 (-23,3\%). Hal ini tidak sejalan dengan teori, dimana seharusnya apabila pendapatan bersih meningkat maka harga saham juga meningkat.

\section{Landasan Teori}

\subsubsection{Pengertian Current Ratio (CR)}

Menurut Isfenti (2010:58), “Current Ratio adalah rasio untuk menghitung kemampuan perusahaan dalam membayar kewajiban jangka pendek dengan aktiva lancar yang tersedia."

\subsubsection{Indikator Current Ratio (CR)}

$$
\text { CurrenRatio }=\frac{\text { Aktiva Lancar }}{\text { Kewajiban Lancar }}
$$

Menurut Sadalia (2010:58), indikator current ratio yaitu:

\subsubsection{Pengertian Net Profit Margin (NPM)}

Menurut Kasmir (2012:200), "Net Profit

Margin (margin laba bersih) merupakan ukuran keuntungan dengan membandingkan antara laba setelah bunga dan pajak dibandingkan dengan penjualan."

\subsubsection{Indikator Net Profit Margin (NPM)}

Menurut Sadalia (2010:63), untuk mengukur laba bersih sesudah pajak dibandingkan dengan volume penjualan.

$$
N P M=\frac{\text { Laba Bersih }}{\text { Penjualan }}
$$

\subsubsection{Pengertian Kebijakan Dividen}

Menurut Hery (2013:14), "kebijakan dividen merupakan keputusan pendanaan perusahaan untuk menentukan berapa besar bagian dari laba perusahaan yang akan dibagikan kepada para pemegang saham dan akan diinvestasikan kembali atau ditahan didalam perusahaan."

\subsubsection{Indikator Kebijakan Dividen}

Menurut Murhadi (2013:65), Dividend Payout Ratio (DPR) merupakan rasio yang menggambarkan besarnya proporsi dividen yang dibagikan terhadap pendapatan bersih perusahaan. DPR diperoleh dengan cara:

$$
D P R=\frac{\text { Dividend }}{\text { Net Income }}
$$

\section{II.4 Harga Saham}

\section{II.4.1 Pengertian Harga Saham}

Menurut Darmadji dan Fakhruddin (2015:10), "harga saham merupakan harga yang terjadi karena adanya permintaan dan penawaran atas saham tersebut."

\section{II.4.2 Indikator Harga Saham}

Menurut Darmadji dan Fakhruddin (2015:102), indikator harga saham adalah Close atau Closing Price menunjukkan harga penutupan saham.

\section{METODE PENELITIAN \\ 3.1 Sumber Data}

Peneliti melakukan penelitian pada Perusahaan Consumer Goods yang terdaftar di Bursa Efek Indonesia sebanyak 43 perusahaan periode 2013-2017 melalui media internet dengan situs www.idx.co.id.

\subsection{Jenis Penelitian}

Jenis penelitian ini adalah penelitian deskriptif. Menurut Sugiyono (2017:100) Penelitian deskriptif adalah jawaban sementara terhadap masalah deskriptif, yaitu berkenaan dengan variabel mandiri.

\subsection{Uji Asumsi klasik}

Penelitian asumsi klasik yang dilakukan untuk menguji asumsi-asumsi yang ada dalam permodelan regresi linear berganda.Pada penelitian ini, asumsi klasik yang akan digunakan terdiri atas uji normalitas, uji multikolineritas, uji autokorelasi dan uji heteroskedastisitas.
3.4 Model Penelitian
1. Uji Koefisien Determinasi $\left(R^{2}\right)$
2. Pengujian Hipotesis secara Simultan (Uji F)


3. Pengujian Hipotesis secara Parsial (Uji t)

\section{HASIL DAN PEMBAHASAN}

4.1 Uji Asumsi Klasik

4.1.1 Uji Normalitas

Tabel 4.1

One-Sample Kolmogorov-smirnov Test Sesudah Transformasi

One-Sample Kolmogorov-Smirnov Test

\begin{tabular}{|ll|r|}
\hline & & $\begin{array}{r}\text { Unstandardiz } \\
\text { ed Residual }\end{array}$ \\
\hline $\mathrm{N}$ & Mean & 95 \\
Normal Parameters & a,b & .0000000 \\
Most Extreme Differences & Std. Deviation & .66783970 \\
& Absolute & .079 \\
& Positive & .079 \\
Test Statistic & Negative & -.073 \\
Asymp. Sig. (2-tailed) & & .079 \\
\hline
\end{tabular}

a. Test distribution is Normal.

b. Calculated from data.

c. Lilliefors Significance Correction.

Tabel IV.1 Hasil pengujian statistik dengan model Kolmogoorov-Smirnov setelah ditransformasi nilai Asymp.Sig (2-tailed) adalah $0,176>0,05$, maka dapat disimpulkan data telah berdistribusi normal.

Penelitian ini menggunakan analisis histogram dan normal probability plot. Analisis histogram dapat disajikan tampilannya sebagai berikut:

Gambar 4.1

Grafik Histogram Sesudah Transformasi Histogram

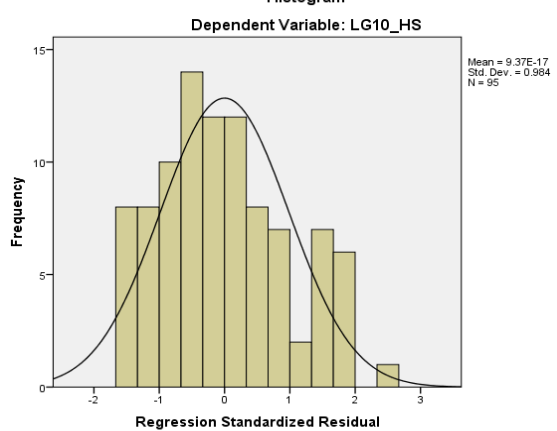

Sumber: Hasil Pengolahan Data 2019

Dari histogram tersebut dapat disimpulkan data residual berdistribusi normal karena histogram tidak menceng ke kanan atau ke kiri.Penelitian ini menggunakan normal probability plot sebagai berikut ini:

Gambar 4.2 : Normal Probability Plot Sesudah Transformasi

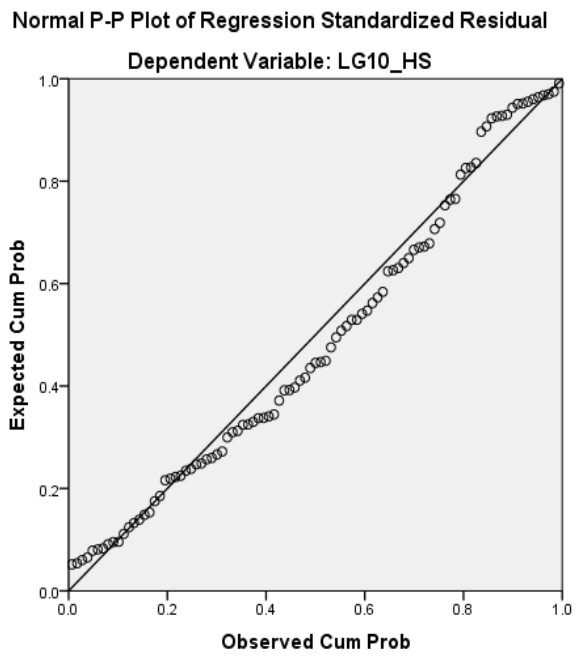

Dari hasil normal probability terlihat titik-titik menyebar disekitar garis diagonal sehingga dapar disimpulkan bahwa data berdistribusi normal.

\subsubsection{Uji Multikolinieritas}

Tabel 4.2

Uji Multikolinieritas Setelah Transformasi

\begin{tabular}{|c|c|c|c|c|c|c|c|c|}
\hline \multirow[b]{2}{*}{ Mode } & & \multicolumn{2}{|c|}{ Unstandardized Coefficients } & \multirow{2}{*}{$\begin{array}{c}\begin{array}{c}\text { Standardized } \\
\text { Coefficients }\end{array} \\
\text { Betata }\end{array}$} & \multirow[b]{2}{*}{$t$} & \multirow[b]{2}{*}{ Sig. } & \multicolumn{2}{|c|}{ Collinearity Statistics } \\
\hline & & $\mathrm{B}$ & Std. Error & & & & Tolerance & VIF \\
\hline \multirow[t]{4}{*}{1} & (Constant) & 3.538 & .243 & & 14.587 & .000 & & \\
\hline & LG10_CR & -1.124 & .352 & -.288 & -3.191 & .002 & .955 & 1.047 \\
\hline & LG10_NPM & 10.783 & 2.639 & .402 & 4.087 & .000 & .805 & 1.242 \\
\hline & LG10_KD & 1.712 & .857 & .192 & 1.998 & .049 & .839 & 1.192 \\
\hline
\end{tabular}

Tabel IV.2 diatas menunjukkan nilai tolerance variabel current ratio $\left(\mathrm{X}_{1}\right)$, net profit margin $\left(\mathrm{X}_{2}\right)$, dan kebijakan dividen $\left(\mathrm{X}_{3}\right)$ masing-masing sebesar $0.955,0,805$, dan 0,839 lebih besar dari 0,10. Nilai VIF yang diperoleh untuk variabel current ratio $\left(\mathrm{X}_{1}\right)$, net profit margin $\left(\mathrm{X}_{2}\right)$, kebijakan dividen $\left(\mathrm{X}_{3}\right)$ masing-masing sebesar 1,047 , 1,242 , dan 1,192 lebih kecil dari 10 maka tidak terjadi multikolinieritas antar variabel independen dalam model regresi tersebut.

\subsubsection{Uji Autokorelasi}

Tabel 4.3

Hasil Uji Autokorelasi Sesudah Transformasi

\begin{tabular}{|l|c|c|c|c|c|}
\hline Model & R & R Square & $\begin{array}{c}\text { Adjusted R } \\
\text { Square }\end{array}$ & $\begin{array}{c}\text { Std. Error of } \\
\text { the Estimate }\end{array}$ & $\begin{array}{c}\text { Durbin- } \\
\text { Watson }\end{array}$ \\
\hline 1 & $.541^{\text {a }}$ & .292 & .269 & .67876 & 1.789 \\
\hline
\end{tabular}
a. Predictors: (Constant), LG10_KD, LG10_CR, LG10_NPM
b. Dependent Variable: LG10_HS

Tabel IV.3 diatas, menunjukkan bahwa current ratio $\left(\mathrm{X}_{1}\right)$, net profit margin $\left(\mathrm{X}_{2}\right)$, dan kebijakan dividen $\left(\mathrm{X}_{3}\right)$ yang diperoleh adalah sebesar 1,789. Maka dapat 
disimpulkan tidak terjadi autokorelasi dalam penelitian

\subsubsection{Uji Heteroskedastisitas}

\section{Gambar 4.3}

Scatterplot Sesudah Transformasi

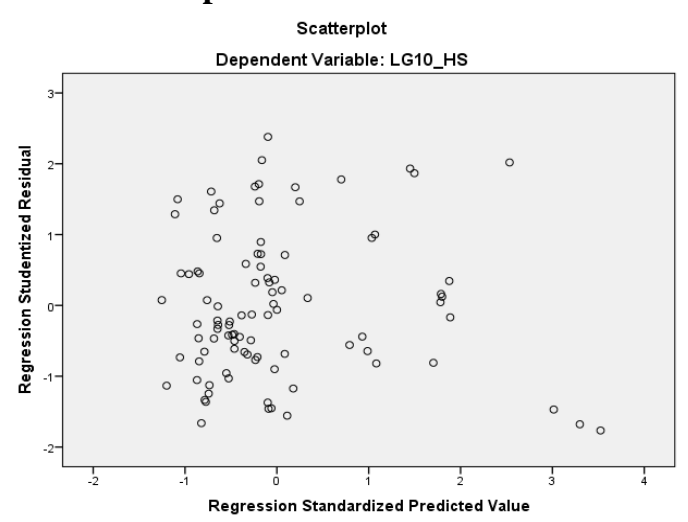

Gambar IV.5 menunjukkan bahwa current ratio $\left(\mathrm{X}_{1}\right)$, net profit margin $\left(\mathrm{X}_{2}\right)$, dan kebijakan dividen $\left(\mathrm{X}_{3}\right)$ danHarga Saham (Y) yang meunjukkan data tersebar acak dan tidak membentuk pola tertentu. Data yang tersebar diatas dan dibawah garis 0 menunjukkan tidak terjadi heteroskedastisitas.

Sedangkan untuk uji statistik dapat dilakukan dengan uji Glejser pada tabel IV.4 berikut ini:

\section{Tabel 4.4}

\section{Hasil Uji Glejser Setelah Transformasi}

\begin{tabular}{|c|c|c|c|c|c|c|}
\hline & & \multicolumn{5}{|c|}{ Coefficients $^{a}$} \\
\hline \multirow[b]{2}{*}{ Model } & & \multicolumn{2}{|c|}{ Unstandardized Coefficients } & \multirow{2}{*}{$\begin{array}{c}\text { Standardized } \\
\text { Coefficients } \\
\text { Beta }\end{array}$} & \multirow[b]{2}{*}{$t$} & \multirow[b]{2}{*}{ Sig. } \\
\hline & & $\mathrm{B}$ & Std. Error & & & \\
\hline \multirow[t]{4}{*}{1} & $\begin{array}{l}\text { (Constant) } \\
\end{array}$ & .341 & .135 & & 2.537 & .013 \\
\hline & LG10_CR & .085 & .195 & .045 & .436 & .664 \\
\hline & LG10_NPM & 3.227 & 1.464 & .249 & 2.204 & .030 \\
\hline & LG10_KD & -.026 & .476 & -.006 & -.055 & .956 \\
\hline
\end{tabular}

Tabel IV.4 di atas menunjukkan hasil signifikan variabel current ratio $\left(\mathrm{X}^{1}\right)$ sebesar 0,664 , net profit margin $\left(\mathrm{X}^{2}\right)$ sebesar 0,030 dan kebijakan dividen $\left(\mathrm{X}^{3}\right)$ sebesar 0,956 dengan hasil signifikan di atas 0,05 maka dismpulkan tidak terjadi heteroskedastisitas.

Tabel 4.5 : Hasil Analisis Regresi Linear

\begin{tabular}{|c|c|c|c|c|c|c|c|c|}
\hline \multicolumn{9}{|c|}{$\underset{\text { Coefficients }^{\mathrm{a}}}{\text { Berganda }}$} \\
\hline \multirow[b]{2}{*}{ Model } & & \multicolumn{2}{|c|}{ Unstandardized Coefficients } & \multirow{2}{*}{$\begin{array}{c}\begin{array}{c}\text { Standardized } \\
\text { Coefficients }\end{array} \\
\text { Beta }\end{array}$} & \multirow[b]{2}{*}{$\mathrm{t}$} & \multirow[b]{2}{*}{ Sig. } & \multicolumn{2}{|c|}{ Collinearity Statistics } \\
\hline & & $B$ & Std. Error & & & & \begin{tabular}{|l} 
Tolerance \\
\end{tabular} & VIF \\
\hline 1 & (Constant) & 3.538 & .243 & & 14.587 & .000 & & \\
\hline & LG10_CR & -1.124 & .352 & -288 & -3.191 & .002 & .955 & 1.047 \\
\hline & LG10_NPM & 10.783 & 2.639 & .402 & 4.087 & .000 & .805 & 1.242 \\
\hline & LG10 KD & 1.712 & .857 & 192 & 1.998 & .049 & 839 & 1.192 \\
\hline
\end{tabular}

Berdasarkan tabel IV.5 di atas diperoleh rumus regresi sebagai berikut :
HargaSaham $=3,538-1,124$ LG10_CR + 10,783LG10_NPM +1,712 LG10_KD

1. Nilai konstanta sebesar 3,358 menyatakan bahwa jika current ratio, net profit margin dan kebijakan dividen dianggap konstan, maka harga saham sebesar 3,358.

2. Nilai koefisien current ratio adalah -1,124. Ini menunjukkan bahwa setiap peningkatan current ratio satu kali makaharga saham akan meningkat sebesar -1,124 kali.

3. Nilai koefisien net profit margin adalah 10,783. Ini menunjukkan bahwa setiap peningkatan net profit margin satu kali maka harga saham akan meningkat sebesar 10,783 kali.

4. Nilai koefisien kebijakan dividen adalah 1,712. Ini menunjukkan bahwa setiap peningkatan kebijakan dividen satu kali maka harga saham akan meningkat sebesar 1,712 kali.

\subsubsection{Koefisien Determinasi}

Tabel 4.6 : Koefisien Determinasi

\begin{tabular}{|l|c|r|r|r|r|}
\hline Model & R & R Square & $\begin{array}{c}\text { Adjusted R } \\
\text { Square }\end{array}$ & $\begin{array}{c}\text { Std. Error of } \\
\text { the Estimate }\end{array}$ & $\begin{array}{c}\text { Durbin- } \\
\text { Watson }\end{array}$ \\
\hline 1 & $.541^{\text {a }}$ & .292 & .269 & .67876 & 1.789 \\
\hline
\end{tabular}
a. Predictors: (Constant), LG10_KD, LG10_CR, LG10_NPM
b. Dependent Variable: LG10_HS

Berdasarkan tabel IV.6 di atas diperoleh nilai adjusted $R$ square $\left(\mathrm{R}^{2}\right)$ koefisien determinasi sebesar 0,269 atau sama dengan 26,9\%. Artinya sebesar 26,9\% variasi perubahan harga saham dapat dijelaskan oleh variabel current ratio, net profit margin,dan kebijakan dividendan sisanya $73,1 \%$ dapat dijelaskan oleh variabel lain di luar model penelitian ini seperti nilai tukar, PBV dan sebagainya.

\subsubsection{Pengujian Hipotesis Secara Simultan} Tabel 4.7 : Hasil Uji Statistik

\begin{tabular}{|ll|r|r|r|c|c|}
\hline \multicolumn{1}{|c|}{ ANOVA $^{\text {a }}$} \\
\hline Model & & $\begin{array}{c}\text { Sum of } \\
\text { Squares }\end{array}$ & \multicolumn{1}{c|}{ df } & Mean Square & \multicolumn{1}{|c|}{ F } & Sig. \\
\hline 1 & Regression & 17.310 & 3 & 5.770 & 12.524 & $.000^{\mathrm{b}}$ \\
& Residual & 41.925 & 91 & .461 & & \\
& Total & 59.235 & 94 & & & \\
\hline
\end{tabular}

a. Dependent Variable: LG10_HS

b. Predictors: (Constant), LG10_KD, LG10_CR, LG10_NPM

Tabel IV.7 di atas, bisa di lihat hasil $F_{\text {hitung }}$ adalah sebesar 12,524> nilai $F_{\text {tabel }}$ adalah sebesar 2,70 maka Ho ditolak dan Ha diterima dengan nilai signifikan $0,000<0,05$ sehingga current ratio,net profit margin,dan kebijakan dividen secara simultan berpengaruh positif dan signifikan terhadap harga saham pada perusahaan consumer 
goods yang terdaftar di Bursa Efek Indonesia periode 2013-2017.

\subsubsection{Pengujian Hipotesis Secara Parsial Tabel 4.8 \\ Hasil Uji Statistik $t$}

\begin{tabular}{|c|c|c|c|c|c|c|c|c|}
\hline \multicolumn{9}{|c|}{ Coefficients $^{\mathrm{a}}$} \\
\hline \multirow[b]{2}{*}{ Model } & & \multicolumn{2}{|c|}{ Unstandardized Coefficients } & \multirow{2}{*}{$\begin{array}{c}\text { Standardized } \\
\text { coefficients } \\
\text { Beta }\end{array}$} & \multirow[b]{2}{*}{$t$} & \multirow[b]{2}{*}{ Sig. } & \multicolumn{2}{|c|}{ Collinearity Statistics } \\
\hline & & $\mathrm{B}$ & Std. Error & & & & Tolerance & VF \\
\hline \multirow[t]{4}{*}{1} & (Constant) & 3.538 & .243 & & 14.587 & .000 & & \\
\hline & LG10_CR & -1.124 & .352 & -.288 & -3.191 & .002 & .955 & 1.047 \\
\hline & LG10_NPM & 10.783 & 2.639 & .402 & 4.087 & .000 & .805 & 1.242 \\
\hline & LG10_KD & 1.712 & .857 & .192 & 1.998 & .049 & .839 & 1.192 \\
\hline
\end{tabular}

Variabel current ratio menunjukkan $-\mathrm{t}_{\text {hitung }}<-\mathrm{t}_{\text {tabel }}$ yaitu $-3,191<-1,986$. Dengan demikian keputusannya adalah Ho ditolak dan Ha diterima, dengan nilai signifikan $0,002<0.05$. Yang berarti terdapat pengaruh yang signifikan antara variabel current ratio terhadap harga saham. Hasil ini mendukung penelitian Yuliana Siti yang menyatakan terdapat pengaruh yang signifikan positif antara perubahan variabel current ratio terhadap harga saham. Akan tetapi, hal ini tidak sejalan dengan teori Sudana $(2011 ; 173)$ yang menyatakan harga pasar saham perusahaan yang terlalu tinggi mengakibatkan berkurangnya likuiditas saham, karena hanya sedikit jumlah investor yang mampu membeli saham perusahaan. Variabel net profit margin mempunyai nilai $t_{\text {hitung }}$ 4,087 dengan nilai signifikan 0,000 sedangkan $t_{\text {tabel }}$ adalah sebesar 1,986 dengan signifikan 0,05. Maka kesimpulannya adalah $t_{\text {hitung }}>t_{\text {tabel }}$ yaitu $4,087>1,986$. Dengan demikian keputusannya dalah Ho ditolak Ha diterima, artinya variabel net profit margin secara parsial berpengaruh positif dan signifikan terhadap harga saham. Hasil ini mendukung penelitian Sari Pustpita yang menyatakan terdapat perubahan signifikan dan positif terhadap perubahan variabel NPM terhadap harga saham.

Variabel kebijakan dividen mempunyai $t_{\text {hitung }}>$ $\mathrm{t}_{\text {tabel }}$ yaitu 1,998> 1,986, Dengan demikian keputusannya adalah Ho ditolak Ha diterima, artinya variabel kebijakan dividen secara parsial berpengaruh positif dan signifikan terhadap harga saham. Hasil ini mendukung penelitian Nurmala yang menyatakan adanya pengaruh yang signifikan positif terhadap perubahan variabel kebijakan deviden terhadap harga saham.

\section{KESIMPULAN DAN SARAN}

\subsection{Kesimpulan}

Berdasarkan penelitian yang telah dilakukan pada perusahaan Consumer Goods yang terrdaftar di Bursa Efek Indonesia Periode 20132017,maka dapat ditarik kesimpulan sebagai berikut:
1. Current ratio, net profit margin dan kebijakan dividen secara parsial berpengaruh positif dan signifikan terhadap harga saham pada Perusahaan Consumer Goods yang terdaftar di Bursa Efek Indonesia Periode 2013-2017.

2. Current Ratio, Net Profit Margin dan Kebijakan Dividen secara simultan berpengaruh positif dan signifikan terhadap harga saham pada Perusahaan Consumer Goods yang terdaftar di Bursa Efek Indonesia Periode 2013-2017.

\section{REFRENSI}

Darmadji, Tjiptono dan Fakhruddin, Hendy M. 2015. Pasar Modal di Indonesia: Pendekatan Tanya Jawab. Edisi 3, Cetakan Ketiga. Jakarta : Salemba Empat.

Ghozali, Imam. 2016. Aplikasi Analisis Multivariate dengan Program IBM SPSS 23. Cetakan VIII. Semarang : Universitas Diponegoro.

Hery. 2013. Rahasia Pembagian Dividen dan Tata Kelola Perusahaan. Cetakan Pertama. Yogyakarta : Gava Media.

Jumingan. 2014. Analisis Laporan Keuangan. Cetakan Kelima. Jakarta

Jusuf, Jopie. 2014. Analisis Kredit untuk Credit (Account) Officer. Cetakan Kedua belas. Jakarta

Kasmir. 2012. Analisis Laporan Keuangan. Ed. 15, cetakan ke-5. Jakarta : Rajawali Pers.

Murhadi, Werner R. 2013. Analisis Laporan Keuangan, Proyeksi dan Valuasi Saham. Jakarta : Salemba Empat.

Sadalia, Isfenti. 2010. Manajemen Keuangan. Medan : USU Press.

Sugiyono. 2017. Metode Penelitian Pendidikan Pendekatan Kuantitatif, Kualitatif dan R\&D. Cetakan Ke-12. Bandung : Alfabeta. 